\title{
A Research on Sensitive Factors of Cross-Border Capital Flows in China
}

\author{
Zhaoyi Xu' ${ }^{1, \text { a }}$, Jiayu Zhu' ${ }^{2, b}$, Joshua Jeanson ${ }^{3, c}$ \\ ${ }^{1}$ College of Finance and Statistics, Hunan University, Changsha 410011, China \\ ${ }^{2}$ College of Finance and Economics, Xi’an International University, Xi‘an, 710128 China \\ ${ }^{3}$ The Wharton School, University of Pennsylvania, Philadelphia, 19104, the USA \\ axuzhaoyi@sas.upenn.edu, b zhujiayu@sas.upenn.edu, JoshuaJ@wharton.upenn.edu
}

Keywords: cross-border capital flow; sensitivity

\begin{abstract}
In recent years, China has actively adjusted the various economic policies and participated in global economic integration. Due to the rapid and steady economy growth, and the increased scale of cross-border capital flows, domestic economy and finance are further deepened and developed. Scholars have researched sensitive factors of cross-border capital flows for a long time and focused on studies related to cross-border capital flows. Since cross-border capital flows differ among times and countries, no sweeping conclusions are drawn, though they have been concerned and studied. This paper analyzes sensitive factors of cross-border capital flows in China from three perspectives: financial factors, basic economic factors and virtual factors. The analysis not only provides an overall understanding of cross-border capital flows in China, but also presents the influencing factors and approaches, thereby facilitating the formulation of related economic and financial policies, avoiding negative impacts of cross-border capital flows on economy, and guiding cross-border capital flows to boost economic growth in China.
\end{abstract}

\section{Introduction}

As the world's largest developing country, China occupies an important position in the world economic system and the international financial market. Therefore, it is of great significance to actively carry out researches on cross-border capital flows in China. On one hand, researches on the current situation, sensitivity and influencing factors of cross-border capital flows in China provide policy suggestions on the effective management and monitoring over cross-border capital flows in China, thereby helping maintain the stability of China's economic and financial systems. They are of great practical significance to the steady development of Chinese economy. On the other hand, the researches provide reference for the resolution of cross-border capital flow problems in developing countries and areas. In addition, the stability of cross-border capital flows is vital to the steady development of world economy.

\section{Literature Review}

The free capital flows between countries not only reasonably allocate financial resources, but also promote economic and financial development of countries, thereby drawing attention of numerous western scholars. With the advancement of internationalization, the scale of cross-border capital flows in China has been expanded since the reform and opening up. In addition, domestic scholars have carried out plenty of related researches. According to the existing literatures, the research results about cross-border capital flows differ among research objects and times, which is closely linked with the changing characteristics of cross-border capital flows. Therefore, it is necessary to profoundly study cross-border capital flows and better promote economic and financial development when preventing risks. Currently, scholars are mostly focused on influencing factors of cross-border capital flows and based on balance-sheet cross-border capital to evaluate cross-border capital flows. 
Although scholars think differently about the attribution of items in BOP tables, they have many things in common. As for the sensitivity of cross-border capital flows, it has been rarely reported. With the scale expansion of cross-border capital flows, however, it has drawn increasing attention. Since the measurement standards for sensitivity are still controversial, they deserve further studies. Both influencing factor and sensitivity measurements of cross-border capital are based on scale evaluation. Implicit cross-border capital flows, which have been neglected, should not be neglected according to the capital control situation in China. In recent years, the scale of cross-border capital flows has been expanded and the sensitivity has been enhanced, which influences financial stability and sustainable economic development to a certain extent and needs to be taken seriously. This paper estimates balance-sheet and implicit cross-border capital simultaneously, with a view to estimate accurate scale of cross-border capital flows and lay the empirical basis for sensitivity analysis. Secondly, the paper performs sensitivity analysis on cross-border capital from two perspectives, namely, time period and time point. Finally, the paper analyzes sensitive factors of the various kinds of cross-border capital, researches the specific influencing approaches and degrees, combines the two and puts forward relevant policy suggestions, thereby providing reference for the management of cross-border capital flows.

\section{Theoretical Basis}

According to the literatures about influencing factors of cross-border capital flows, interest-rate differential is an important factor influencing cross-border capital flows, both theoretically and empirically. From the perspective of finance, bank saving deposit is the most liquid and the least risky investment activity while bank interest revenue is the minimum investment income and the opportunity cost of other investments. Therefore, the huge interest-rate differentials between China and other countries provide riskless arbitrage opportunities for international capital, thereby causing cross-border capital flows. When domestic interest rates exceed foreign interest rates, domestic expected rate of return is higher than that in foreign countries, which causes capital inflows.

With the vigorous development of the international financial market, cross-border capital has gotten rid of the past profit model (investment - production - sales) and international capital has chosen to earn speculative profits by investing in financial markets. When cross-border capital is used to invest in real economy, the appreciation of RMB exchange rate will raise production costs in China, reduce profits, increase funding pressures on international enterprises and accumulate risks of exchange rate fluctuations, thereby inhibiting cross-border capital inflows or intensifying cross-border capital outflows. When cross-border capital is used to invest in virtual economy and aimed to earn speculative profits, the appreciation or fluctuation of RMB exchange rate will promote inflows of international capital. The theoretical bases lay a solid foundation for subsequent empirical researches and promote the progress of model estimation and result examination.

\section{Variable Selection and Data Description}

The empirical analysis of sensitivity of cross-border capital in China is based on the previous research results. This paper introduces the three most important indexes for description (variables not stated are deemed as control variables and listed in the model).

(1) Economic growth: economic growth (the growth of material wealth) relies heavily on the exploitation of natural resources, the expansion of capital accumulation and the innovation of technology. PPI (Producer Price Index), which is also known as ex-factory price index of industrial products, measures changing trends and degrees of ex-factor prices of industrial products. In the meantime, it reflects price changes of products at different production stages. This paper utilizes PPI to measure economic growth in China. The data comes from National Bureau of Statistics of the People's Republic of China.

(2) Balance of payments: with the development of economic globalization, countries have conducted various economic and trading activities with each other, in the process of which the 
balance of payments is widely used to measure achievements of the economic activities. In the balance of payments, current account balance of a country represents the transfer of tradable goods and service resources between the country and other countries and reflects foreign economic development and relations of the country in open economy, including trade structure, trade terms and external competitiveness. Therefore, this paper introduces current account balance to measure the balance of payments in China and represents the variable with CAB.

(3) Price level: the variable is represented by GDP. This paper selects GDP deflator to measure the price level in China. GDP deflator involves quantity and price of all products and services of a country, thereby reflecting changes in the general price level and fluctuations in prices. It is deemed as an important index to measure the general price level. As the ratio between nominal GDP and real GDP, GDP deflator reflects the current level of prices relative to the level of prices in the base year. The data comes from Wind Info.

\section{Empirical Modeling and Result Testing}

Based on the research of Tian Meiyu (2016), this paper analyzes sensitivity of cross-border capital flows with total cross-border capital flows. Wherein, the sensitivity of cross-border capital flows is deemed as the explained variable. Since the value of the explained variable is based on the discrete binary choice model, Logit regression models are employed to test statistical methods for sensitivity of capital flows, as shown below:

$$
\ln \left(\frac{\mathrm{p}}{1-\mathrm{p}}\right)=\beta_{0}+\beta_{1} \mathrm{PPI}+\beta_{2 \mathrm{CAB}+} \beta_{3 \mathrm{GDP}+} \beta_{4 \mathrm{RATE}+} \beta_{5 \mathrm{STOCK}}+\beta_{6 \mathrm{RMB}}+\beta_{7 \mathrm{INDEX}+}{ }^{\varepsilon}
$$

After establishing regression models, the paper conducts significance tests on correlation coefficients of the various variables and represents the results with asterisks. Wherein, three stars show that the variable is significant at the $1 \%$ level; two stars show that the variable is significant at the $5 \%$ level; one star shows that the variable is significant at the $10 \%$ level. The following table demonstrates the test results on correlation coefficients of regression models obtained by virtue of EVIEWS8.0.

\begin{tabular}{|c|c|c|c|c|c|c|c|c|c|}
\hline (obs=3690) & PPI & $\mathrm{CAB}$ & GDP & RATE & STOCK & RMB & INDEX & FINANCE & OPEN \\
\hline PPI & 1 & & & & & & & & \\
\hline CAB & $0.625^{* * *}$ & 1 & & & & & & & \\
\hline GDP & $\begin{array}{l}-0.380 * * \\
*\end{array}$ & $\begin{array}{l}-0.107 * * \\
*\end{array}$ & 1 & & & & & & \\
\hline RATE & $0.128 * * *$ & $0.128 * * *$ & $\begin{array}{l}-0.200 * * \\
*\end{array}$ & 1 & & & & & \\
\hline STOCK & -0.0260 & -0.0250 & -0.00500 & 0.0210 & 1 & & & & \\
\hline RMB & $\begin{array}{l}-0.233^{* *} \\
*\end{array}$ & $\begin{array}{l}-0.272 * * \\
*\end{array}$ & $0.148^{* * *}$ & $\begin{array}{l}-0.152 * * \\
*\end{array}$ & -0.00500 & 1 & & & \\
\hline INDEX & $0.150 * * *$ & 0.0100 & $\begin{array}{l}-0.143^{* *} \\
\quad *\end{array}$ & $0.092 * * *$ & -0.00700 & $\begin{array}{l}0.428 * * \\
*\end{array}$ & 1 & & \\
\hline FINANCE & $0.107^{* * *}$ & $0.031^{*}$ & $\begin{array}{l}-0.165^{* *} \\
\quad *\end{array}$ & $0.069 * * *$ & $\begin{array}{l}-0.074 * * \\
*\end{array}$ & $0.029 *$ & $0.038^{* *}$ & 1 & \\
\hline OPEN & $0.087 * * *$ & $0.108 * * *$ & $\begin{array}{l}-0.104 * * \\
*\end{array}$ & $0.031^{*}$ & -0.0150 & 0.0110 & $\begin{array}{l}0.170^{* *} \\
*\end{array}$ & $\begin{array}{l}0.039 * \\
*\end{array}$ & 1 \\
\hline
\end{tabular}

The above equation reveals significance of the various variables. Judging from the signs of the variables, price level (GDP) is negative, indicating that capital inflows increase with the decrease in inflation; economic growth (PPI) is positive, indicating that favorable domestic economic environment and international investment environment are conductive to capital inflows; interest-rate differential (RATE) is positive, indicating that capital inflows increase when domestic rate of return on financial assets exceeds that in foreign countries; stock price (STOCK) is positive, indicating that the domestic stock market promotes capital inflows; exchange rate (INDEX) is positive, indicating that RMB appreciation increases capital inflows; RMB internationalization degree (RMB) is negative, indicating that capital outflows are intensified with the increase in RMB convertibility and 
acceptability; international financial environment (FINANCE) and capital account openness (OPEN) are positive, indicating that capital inflows are large when capital account openness is high and the international financial environment is favorable. All these are in line with the economic expectations.

\section{Conclusion}

This paper starts from the trends and structural changes of cross-border capital flows, analyzes cross-border capital flows in China from three perspectives (inflow, outflow and overall trend), and estimates balance-sheet and implicit cross-border capital flows, thereby laying a solid foundation for subsequent empirical analysis. The following conclusions are drawn: total cross-border capital is significantly influenced by basic economic factors (economic growth, price level and balance of payments) virtual factors (capital account openness, international financial environment and RMB internationalization degree), interest rate and real estate price. The impact of exchange rate and stock price is not significant. When financial factors are affected, responses of overall cross-border capital toward interest rate and real estate price are positively stabilized while those toward exchange rate and stock price are negatively stabilized. Balance-sheet cross-border capital is significantly influenced by basic economic factors (economic growth, price level and balance of payments), financial factors (exchange rate, interest rate, stock price and real estate price) and virtual factors (excluding RMB internationalization degree).

\section{References}

[1] AHMET FARUK AYSAN. MACROPRUDENTIAL POLICIES AS BUFFER AGAINST VOLATILE CROSS-BORDER CAPITAL FLOWS[J]. Singapore Economic Review, 2015, 60(01):1550001.

[2] Giovanni J D. What drives capital flows? The case of cross-border M\&A activity and financial deepening[J]. Journal of International Economics, 2005, 65(1):127-149.

[3] Ueda K. Comment on "Global Imbalances and the Financial Crisis: Reassessing the Role of International Finance”[J]. Asian Economic Policy Review, 2010, 5(2):219-220.

[4] Steiner A. CONTAGIOUS POLICIES: AN ANALYSIS OF SPATIAL INTERACTIONS AMONG COUNTRIES' CAPITAL ACCOUNT POLICIES[J]. Pacific Economic Review, 2010, 15(3):422-445.

[5] Taylor A M. Argentina and the world capital market: saving, investment, and international capital mobility in the twentieth century 1[J]. Journal of Development Economics, 1998, 57(1):147-184.

[6] Delbin M A, Antunes E, Zanesco A. The determinants of cross-border bank flows to emerging markets: New empirical evidence on the spread of financial crises[J]. Economics of Transition, 2013, 21(3):479-508. 